\title{
TRANSNATIONALITY AND NATIONALISM: SHARED AND CONTESTED MEMORIES OF WU LIEN-TEH ACROSS EAST AND SOUTHEAST ASIA IN POST-SARS ERA
}

\author{
Por Heong Hong * \\ Malaysian Chinese Research Centre, \\ University of Malaya, 50603 Kuala Lumpur, Malaysia \\ email: floody26@gmail.com
}

Published online: 15 July 2016

To cite this article: Por, H. H. 2016. Transnationality and nationalism: shared and contested memories of $\mathrm{Wu}$ Lien-Teh across East and Southeast Asia in post-SARS era. International Journal of Asia Pacific Studies 12 (2): 83-103, DOI: 10.21315/ijaps2016.12.2.4

To link to this article: http://dx.doi.org/10.21315/ijaps2016.12.2.4

\section{ABSTRACT}

Maurice Halbwachs proposed that the reading of the pasts is shaped by interests and needs of the present. The surging interest in Wu Lien-TehPenang-born, Cambridge-trained plague fighter in China-across East and Southeast Asia in post-SARS era appears to affirm Halbwachs' view. Utilising Halbwachs' presentist and constructionist approach, this article reads post-SARS memories of Wu Lien-Teh as a contested terrain where various historical actors, under a mix of fortuitous as well as intentional circumstances, come to construct what they presently perceive as relevant and important. Memories of the past is thus a site that tells about the present. Drawing on a variety of publications and online sources, this article makes post-SARS accounts of Wu in the region a case for the study of how the pasts are reconstructed to communicate the present. Given that the commemoration of Wu spans across various countries, the case also allows investigation of memory variation across the region. The findings show that the reconstruction of Wu's pasts in the region has been shaped by varying subjective concerns of different historical actors, politics and social conditions in the region, and the transnationality, locality and materiality of Wu's legacies. Despite that the memories of Wu are embedded in a 
transnational network and have been variedly framed in different countries, they are narrated in present terms and tend to intertwine with nationalist narratives.

Keywords: $\mathrm{Wu}$ Lien-Teh, epidemics, social memories, transnationality, nationalism, Southeast Asia

\begin{abstract}
"Society from time to time obligates people not just to reproduce in thought previous events of their lives, but also to touch them up, to shorten them, or to complete them so that, however convinced we are that our memories are exact, we give them a prestige that reality did not possess." - Halbwachs 1992: 51
\end{abstract}

\title{
INTRODUCTION
}

Much has been written about $\mathrm{Wu}$ Lien-Teh-Penang born, Cambridge University-trained medical doctor-who became a world-renown plaque fighter after successfully combating a pneumonic plaque outbreak, which killed over 60,000 persons in Manchuria, China, in 1910-1911 (Flohr 1996; Gamsa 2006; Ho 2000; Knab 2011; Lee et al. 2014; Lei 2010; Luesink 2009; Wang 2007; Wong 2007; Wu 1995). This article does not seek to trace what has been written about $\mathrm{Wu}$ and his legacies in epidemic prevention and public health from early 20th century to the present. How and in what context Wu's legacies have been remembered, especially in the renewed interest in his pasts among communities in China, Singapore and Malaysia over the past decade, is the focus of this article. Neither does this article intend to argue whether or not $\mathrm{Wu}$ should be remembered or which legacies of Wu deserve more highlighting. Rather, it aims to explore and answer why $\mathrm{Wu}$ Lien-Teh has been memorialised in a particular historical juncture and in a particular frame of reference or narrative. ${ }^{1}$

Despite Wu's impressive achievement during the first quarter of the 20th century, his legacies almost went unnoticed in China and his hometown Penang for over four decades, until the eruption of SARS in East and Southeast Asia in 2003. The reappearance of Wu's stories in the recent past decade invites questions. What intrigues me is the timing and pattern of the recent commemoration. There have been several episodes of epidemic outbreak in the region, including the Nipah Virus outbreak in Malaysia in 1998, and the SARS and the avian flu pandemics in both East and Southeast Asia in 2003 and 2009 respectively, since the passing of $\mathrm{Wu}$ in 1960. The earlier outbreak in 1998, however, did not spark interest in Wu's legacies in 
epidemic prevention. The timing of the recent remembrance activities thus raises a few questions: Why earlier pandemic in Malaysia did not spur interest in $\mathrm{Wu}$ ? Why and how did SARS outbreak come to ignite interest in $\mathrm{Wu}$ ? What does the timing tell us about Wu's legacies and the changing dynamics of the wider domestic as well as regional conditions, in which his legacies were first obscured and later reconstructed?

This article is not a historical study of $\mathrm{Wu}$ Lien-Teh. Instead, its major concern centres around post-SARS memorialisations of $\mathrm{Wu}$, and social and political dynamics that shape these activities and the contents of memories. As proposed by Halbwachs (1992), the reading and comprehension of the pasts is constantly influenced by interests and needs of the present. The emerging interest in Wu's anti-plague legacy in postSARS era appears to affirm Halbwachs' view. Utilising Halbwachs' presentist and constructionist approach, this article is an analytical exercise that views post-SARS memories of $\mathrm{Wu}$ Lien-Teh as a contested terrain where various historical actors, under a mix of fortuitous as well as intentional circumstances, come to construct what they presently perceive as relevant and important. Recollection of the past is thus a site that also tells us about the present realities.

Drawing on a variety of publications and online sources, this article makes post-SARS accounts of $\mathrm{Wu}$ in the region a case for the study of how the pasts are reconstructed to communicate the present. Intellectual reflections on Wu's pasts, though shared among relatively smaller group of people compared to other materials produced for mass circulation, are also included because they represent a distinctive strand of collective thought. As argued by Halbwachs (1992: 40), "one may say that the individual remembers by placing himself in the perspective of the group, but one may also affirm that the memory of the group realizes and manifests itself in individual memories." In other words, reflections and memories of individuals are always embedded in collective ones. Moreover, individuals, including scholars, are simultaneously members of different groups. Not only that an individual's activities of remembering are always embedded in collective ones, "the memory of the same fact can be placed within many frameworks, which result from distinct collective memories" (Halbwachs 1992: 52). Put otherwise, scholarly reflections not only represent a specific tradition of intellectual inquiry, they also represent a unique strand of collective thought. For this reason, this article also presents the intellectual discourse on Wu's pasts by Sinophone Southeast Asian intellectuals of Chinese ethnic origin as a site of memories to investigate their present concern. 
Apart from looking at what is recollected, I will also pay attention to what is obscured. As indicated by earlier studies on memories, remembrance of the pasts, influenced by a wide range of social conditions, is simultaneously an activity of forgetting. What has been underemphasised is as important as what has been brought forward in marking out what people presently conceive as significant (Bong 2014; Halbwachs 1992; Koh 2013; Paez et al. 1997; Radley 1990; Schwartz 1990; Sorek 2015). Given that the commemoration of $\mathrm{Wu}$ spans across various countries, the case also allows investigation of memory variation across the region. I will show that the commemorations of $\mathrm{Wu}$ have been differentially determined by a variety of circumstances, which include: (1) the transnational intellectual network that exchanges and generates memories of $\mathrm{Wu}$; (2) varying subjective concerns of different historical actors; (3) the transnationality and locality of Wu's legacies; (4) the materiality and locality of Wu's legacies, e.g., hospital, publication and writings, residence, etc.; and (5) diverse social, cultural and political conditions in the region.

By transnationality, this article refers to three different but closely related notions: 1) the movement of people, ideas and information across nations and regions; 2) the exchange of ideas and information among people of different nations within a particular nation's geographical boundary; and 3 ) the hybrid characteristics of an individual, such as Wu Lien-Teh, who has lived transnational experience, whether via movement across space or through exchange of ideas and cultures. ${ }^{2}$ As existing literature shows, both Chinese nationalism and the institutionalisation of public health are embedded in and shaped by transnational forces (Duara 1997; Knab 2011; Lei 2010). The major argument of this article is that, post-SARS memorialisation of $\mathrm{Wu}$ in the region too, has been shaped by both national as well as transnational forces in each country. "Transnationality" is not only a method to describe a regionally connected network or the hybridity of culture and people, it is also an approach that decentres the place of nation state in order to complicate the picture of memory construction. In China, the remembrance of $\mathrm{Wu}$ has been a nationalistically driven political mobilisation to respond to perceived shortcoming of the country's healthcare after the outbreak, despite the transnational nature of these activities and the hybridity of $\mathrm{Wu}$. Nevertheless, nationalistically charged narrative of $\mathrm{Wu}$ encounters contestation when it takes place in Malaysia. The variation of historical remembrance regarding $\mathrm{Wu}, \mathrm{I}$ argue, speaks to the ethnically and ideologically heterogenous landscape of Southeast Asia and the cultural politics in the region.

I arrange the article into three sections before drawing on a conclusion. I will begin with historicising the fading of Wu's name in places 
where he had left his legacies and explains why the SARS ignited interest in $\mathrm{Wu}$ first started in China and not his birthplace Penang. The second part deals with the transregional commemoration activities in Singapore and China, two countries where Wu's pasts are associated with and also worst hit by SARS, and later move on to visit the remembrances of $\mathrm{Wu}$ in Penang and the transnational reconstruction of Wu's pasts. The last section examines shared and varied memories of $\mathrm{Wu}$ against the background of cultural politics and other political economic dynamics in the region.

\section{DISAPPEARANCE OF WU'S NAME: INTERNAL POLITICS, LINGUISTIC ELEMENT AND LOCALITY OF LEGACY}

A brief hark back to Wu's past is necessary before examining the vanishing and the reappearance of his name. In 1910, Wu Lien-Teh left Penang at the age of 31, after the conviction of opium possession which was set against his involvement in anti-opium advocacy, and spent nearly three decades in China (Wu 1959). When he left China in 1937, he left his three-decade antiplaque and preventive medicine legacies to a country ridden with wars and internal political conflicts for over four decades. As an English-educated intellectual, his scholarly work in China was entirely written in English. During the Cultural Revolution in the 1960s, a project that sought to translate the History of Chinese Medicine, a tome co-authored by $\mathrm{Wu}$ and China-born Western-trained medical doctor Wang Jin-Ming and published in Tientsin in 1932, into Chinese, was put to halt as the book was regarded as "too conciliatory to imperialist aggression" (Luesink 2009: 164). Wu and Wang were also deemed lack of sufficient knowledge of Chinese medicine to write about its history. Linguistic element and political situation were unpromising to the transmission of Wu's scholarly legacy in China (Wang 2007: 215).

The situation in his home country, Malaya, was slightly different. $\mathrm{Wu}$ completed and published his 667-page autobiography in 1959, barely a year before his passing in Penang. By the time he passed away, only half of the population in Malaya were able to read; the size of English literate community was even smaller, posing a social condition not optimistic for the circulation of his autobiography. The absence of artefacts, such as infrastructures of public health and modern medicine $\mathrm{Wu}$ had constructed in China, was equally unpropitious to passing on his legacies. Artefacts or material forms of the pasts are elements of the pasts on which interpretations and memories can be constructed (Sorek 2015; Radley 1990). Without such tangible forms of Wu's past, his name soon faded into 
oblivion in his home country for over four decades, despite being worldwidely mourned as a loss to the field of medicine upon his death. The internal politics in China, the social condition in Malaya, and the nature and locality of Wu's legacies all came to constitute a mix of situations unfavourable to the passing of his legacies, until the outbreak of SARS in 2003.

But why did post-SARS enthusiasm of Wu's past emerge in China first, and not in his birthplace Penang? Why earlier pandemics in Malaysia, such as Nipah Virus outbreak in 1998, and bird flu and swine flu in 2009, did not come to spark the same interest among Malaysians in Wu as SARS did in China? Perhaps the cue lies in the nature and the locality of Wu's legacies. Even if Malaysians had felt a sense of urgency to revisit past pandemics and rediscover possible preventive measures in their homeland during earlier episodes of outbreaks before the eruption of SARS in 2003, they were unlikely to encounter the name of $\mathrm{Wu}$, as the anti-epidemic legacies $\mathrm{Wu}$ constructed, whether the public health infrastructure or his scholarly work, were associated to China. The eruption and severeness of SARS in China was thus a haphazard crucial to arousing interests in stories of Wu buried or suppressed for over four decades in the region. Different from the situation of Malaysia and China, the significance of Singapore in the reconstruction of Wu's past lies in Wu's family. Wu's eldest daughter, $\mathrm{Wu} \mathrm{Yu}$-Ling, kept a wealth of information about her father and she herself was a centre of intellectual network in the region. ${ }^{3}$ It took just an unintentional circumstance, the outbreak of SARS, to ignite people's interest in the pasts, which immediately led to the rediscovery of $\mathrm{Wu}$, the activation and expansion of the network, and the intensification of memory sharing. Singapore also plays a role in generating and circulating knowledge about $\mathrm{Wu}$ in English and stirring interest beyond the Sinophone circle in the region. The memorialisation of $\mathrm{Wu}$ in Penang is slightly different. The timing when local community began to commemorate Wu's legacies coincided with Georgetown's acquisition of United Nations Organizations for Education, Science and Culture (UNESCO) world heritage status, which is simultaneously a cause and an outcome of the community's interest in archiving the city's pasts, whether for the purpose of rebranding the city or for the search and reconstruction of the city's identity.

From China to Singapore and Penang, the memorialisation of $\mathrm{Wu}$ reveals a transnational connection and shared memories in the region. The following section will further explore how people in this transnational network of remembrance connect to each other. 


\section{TRANSNATIONAL NETWORK: FROM FAMILY MEMORY TO SARS AROUSED COMMUNITY INTEREST}

Prior to the eruption of SARS in 2003, there were already scattered transnational efforts, especially among elites in Singapore and China, in commemorating Wu's legacies (Wang 2007; Wu 1995). The publication of "Memories of Dr Wu Lien-Teh: Plague Fighter" by Wu Lien-Teh's daughter, $\mathrm{Wu} \mathrm{Yu}$-Ling, who is also a Singapore-based retired bilingual educationist, in 1995, and her attendance in the 80th anniversary of National Medical Association of China (中华医学会) ${ }^{4}$ in Shanghai, China, the same year, were two among such efforts. Despite its transnational nature, these commemorative activities were confined within a small circle between Wu's family and intellectuals in China (Wang 2007: 288).

A decade later, the casualty caused by SARS in China stirred up hunger among Chinese intellectuals to revisit earlier episodes of epidemics and preventive measures in their own country. A wave of enthusiasm in search of Wu's legacies started and went beyond the circle of physicians, scientists and historians. Cheng Guang-Sheng (程光胜), microbiologist in the Chinese Academy of Sciences, who stumbled upon Wu's name since the late 1980 s, took the opportunity to remind his fellow men of Wu's anti-epidemic legacies in China by writing and publishing an article entitled "Wu LienTeh: The Pioneer in China's Anti-epidemic Science" in May 2003. ${ }^{5}$ Another character, Li Luer (礼露), who was a journalist, came across the name of $\mathrm{Wu}$ while earnestly looking up stories of past pandemics in her own country after surviving SARS infection. Struck and moved by Wu's work, Li Luer began to delve deeply into the history of $\mathrm{Wu}$ and later became one of the key persons in rebuilding Wu's legacies in the region. Li Luer's article, entitled "Wu Lien-Teh: The Pioneer of Modern Medicine in China," was published in Hainei Yu Haiwai (海內海外 or The Local and the Overseas) on 8 September $2005 .{ }^{6}$ Wang Zhe, (王哲) medical doctor, later contributed a book titled "Guoshi Wushuang Wuliende" (国士无双伍连德 or Wu Lien Teh: A National Scholar of No Equal) in $2007 .^{7}$

The revelation of $\mathrm{Wu}$ Lien-Teh as the first Chinese nominated for Nobel Prize in Medicine in 1935 during the declassification of Nobel's nomination database in 2007 further heated up the enthusiasm. A series of publication that frames $\mathrm{Wu}$ as a "patriotic overseas Chinese who returned to China at the turn of $20^{\text {th }}$ century and established modern medicine in his homeland" emerged and flooded the internet since then. Li Luer's book, entitled "Discover Dr. Wu Lien-Teh: The First Chinese Nobel Nominees," was published in 2010; Wu's 667-page autobiography, first published in Cambridge in 1959, was jointly translated by Cheng Guang-Sheng and Ma 
Xue-Bo (马学博) into Chinese and published in 2011. In addition to publication, efforts were also taken to reconstruct Wu's legacies in material form, which include preserving Wu's former residence in Beijing and the establishment of $\mathrm{Wu}$ Lien-Teh Memorial Museum in Harbin on 8 September 2008. ${ }^{8}$

While the Chinese intellectuals and the wider community in China were retrieving the past of $\mathrm{Wu}$, Ong Lay Hong, a bi-lingual senior TV and documentary producer in Singapore's Media Corp, who had not a single knowledge of $\mathrm{Wu}$, came to stumble upon Wu's story while having a conversation with a veteran broadcaster in 2006. Aroused by the stories, Ong decided to interview $\mathrm{Wu}$ Yu-Ling, who immediately put Ong into contact with a transnational network of intellectuals and a rich repertoires of information about $\mathrm{Wu}$ Lien-Teh. Though felt the urgency to weave the pasts of $\mathrm{Wu}$, Ong's wish to produce a documentary on $\mathrm{Wu}$ was deterred by the lack of sufficient funds. Further encouragement came when Li Luer and Lin Guan-Zhen (林冠珍), ${ }^{9}$ prompted by their personal interest in search of Wu's stories in Southeast Asia, made a self-sponsored trip to Singapore in September 2007. Both took the opportunity to persuade their Singaporean counterparts to jointly produce a documentary on $\mathrm{Wu}$, an event which coincided with Ong's promotion as a team leader responsible for developing China's market for Media Corp owned Channel News Asia (CNA). Li Luer was later employed as a researcher when a production team led by Ong was formed with grants approved by CNA. ${ }^{10}$

The transnational network via which memories of $\mathrm{Wu}$ were exchanged and woven began to extend beyond Wu's family in Singapore, as scattered regional efforts came to connect one another. In April 2008, a documentary on $\mathrm{Wu}$ jointly produced by the Chinese and the Singaporeans was screened in Beijing. Though the documentary is narrated in Mandarin, its English subtitle helps the film to reach beyond Sinophone audience and the online coverage of the screenings further allows distribution beyond Singapore. ${ }^{11}$ More transnational commemoration activities in the region came up since then, including a seminar on $\mathrm{Wu}$, organised by the Singapore China Friendship Association (SCFA 2011) and held in Singapore, on 14 April 2011; "Dr. Wu Lien-Teh Commemorative Symposium" held in Harbin, China, in 2013, which Ong Lay Hong and Penang-based scholar Fazal Anwar were two among the invited speakers; and the "Plague Fighter Dr. Wu Lien-Teh: International Conference and Exhibition" in Nanyang Technological University, Singapore, in April 2014, at which Cheng GuangSheng and Clement Liang ${ }^{12}$ were invited to deliver a speech. 
On the other side of the Singapore-Malaysia causeway, Malaysians seemed to be largely oblivious of Wu's existence. Despite that a sport house in Penang Free School, where $\mathrm{Wu}$ received his primary and secondary education, has been named after him for decades, little had been explained to the students, leaving his stories unknown even among old Free Schools. ${ }^{13}$ Not until the recent regional wave of rediscovery that Malaysians in the northern part of the peninsula came to associate Taman Wu Lien-Teh, a private road near Free School named after him in Penang, and Jalan $\mathrm{Wu}$ Lien-Teh, a road in Ipoh, to a figure newly known to them, the "plague fighter" who left Penang in 1910 and returned to Malaya in 1937 to escape the war-ridden China. A book chapter about Wu authored by Ho Tak Ming in 1983 but published in 2000 and known only to a tiny intellectual circle, was reprinted by the Penang-based Dr. Wu Lien-Teh Society (WLTS) for free circulation since 2013. The community interest in $\mathrm{Wu}$ emerged around 2011, when some Penang-based bloggers and intellectuals stumbled upon Wu's name, either via Chinese publication in China ${ }^{14}$ or English ones in Singapore through the internet, ${ }^{15}$ and started blogging about him. The SCFA organised seminar on $\mathrm{Wu}$ in Singapore on 14 April 2011 also came to inform some Malaysians the legacies of $\mathrm{Wu} .{ }^{16}$ Nevertheless, in contrast to the image of "patriotic overseas Chinese" in China, Wu Lien-Teh has been regarded as "a name Malaysian should be proud of," "anti-opium pioneer," "internationally acclaimed plague fighter" and "one of the three famous Straits Chinese in early twentieth century" in his home country.

People in two sectors in Penang - the heritage conservation sector and tourism sector-have been particularly concerned about Wu's past. Driven by a mix of varied intentions, including the quest of the pasts and identity, the demand of cultural rebranding, etc., they began to relate Wu's legacies to their work. It was against this background that WLTS was established on 14 October 2012 and became an association actively engaged in regional commemoration activities with its counterparts in Singapore and China. Present at the inaugural meeting of WLTS were representatives from Penang Heritage Trust, Penang Global Tourism, Penang Tourist Guides Association, Penang Budget Hotels Association and Penang Medical College ${ }^{17}$ The community's increasing interest in Georgetown's pasts is associated with the declaration of Georgetown as a UNESCO world heritage site in 2008, which demands various concerned sectors on the island to be proactive in conserving their heritage and generating histories of the designated site, if the status and business as usual is to be maintained.

However, compared to their counterparts in China and Singapore in their recent transnational search of Wu's past, community in Penang have been relatively less aggressive. Clement Liang, treasurer of WLTS, 
commented, "Wu Lien-Teh is better remembered in Singapore than in Penang, despite that his life had much association with Penang than with Singapore. His stories are never aired on Astro or any local TV stations... a prominent figure lightly taken by his own fellows. He is [only] memorized as a Straits Chinese in Singapore." ${ }^{18}$

These regional activities bring to our attention that the same figure has been variedly remembered across the region. Why did the memorialisation of the same figure differ from one place to another? What are the wider dynamics that shape the memorialisation of $\mathrm{Wu}$ ? What does varying focuses on Wu's pasts tell us about the wider dynamics in the region? The next section will visit the shared features as well as the variations in the memories of $\mathrm{Wu}$.

\section{(DIS)LOYALTY OF A PLAGUE FIGHTER: SHARED AND CONTESTED MEMORIES OF WU}

Across the region, Wu Lien-Teh has been commonly remembered as "a world-renown plague fighter" and "a forgotten hero." Another shared feature in various accounts of $\mathrm{Wu}$ is the teleological and triumphalist narrative of modern medicine and public health in China, his "great contribution to human race, medical science and public health." The variations found in different accounts of Wu's pasts lie in narratives about: (1) his identity, such as whether he is a Chinese, an Overseas Chinese or a Malayan; (2) where did his loyalty go to, China or Malaya?

Without ignoring Wu's birthplace, Malaya, the accounts of $\mathrm{Wu}$ generated in China repeatedly frame him as "a patriotic Overseas Chinese" who "returned" to China and made great contribution in modernising medicine and public health in his "homeland." Han Qi-De (韩启德), a medical scientist and the Vice-president of the National People's Congress of China who penned the preface of Wang Zhe's book (2007), condenses the life of $\mathrm{Wu}$ into a patriotic narrative:

"Wu Lien-Teh is not only an internationally renowned scientist, he is also a role model of patriotic intellectual. In his entire life, he attributed the great achievement he had made and the honor gained to his homeland who gave him the opportunity to serve his own nation. He was proud to have contributed to his homeland, he was also pleased to have relieved the people from sickness and to have improved the people's health. 
$\mathrm{Wu}$ Lien-Teh was born in Nanyang's Penang and trained in medical education in England. He later determinedly returned to his homeland to serve his own nation, he contributed his most precious years in constructing China's health and epidemic prevention system."

As a matter of fact, it was part of the Chinese authority's interest to promote patriotism. In the concluding paragraphs, Wang (2007: 288) relates Wu's "nation loving" story to the current disastrous experience of SARS outbreak and reveals the Chinese authority's engagement in using Wu's story to promote nation loving spirit:

Despite that $\mathrm{Wu}$ Lien-Teh has regained recognition among the Chinese scientist circle, [he] remains unknown to the general Chinese people; even the wider science workers, including many medical and health personnel, are ignorant [about $\mathrm{Wu}$ ]. Although that part of Chinese history has been repeatedly woven into numerous fictions and acts, turned into films and screened for countless times, that even thieves and robbers are informed about it, yet no one informs us about $\mathrm{Wu}$, whose achievement in those years deserves only two words "wei $d a "$ [meaning "great"].

The society has become increasingly obsessed with private interest and restless, as $\mathrm{Wu}$ Lien-Teh becomes more and more removed from us, almost as distant as the twinkling star in the sky.

In the spring of 2003, the rampage of SARS in Beijing was as destructive as the arrival of the doomsday. Just like the encounter in India nine years back, people were stricken by panic and fear and held by resentment during the sudden outbreak of epidemic. They had to endure all kinds of excuses. Not until the fog of history dissipated that they began seeing the figure of a great medical doctor and soldier who had determinedly walked to Harbin.

In the aftermath of SARS, many people began to call the name of $\mathrm{Wu}$ Lien-Teh and understand him. Every contact with $\mathrm{Wu}$ Lien-Teh across time and space has intensely touched the heart of people. The nation loving spirit as expressed by $\mathrm{Wu}$ Lien- 
Teh has been widely promoted by the authority... Wu Lien-

Teh finally walks out of history and returns to China. ${ }^{19}$

In this nation loving narrative, "Wu Lien-Teh" is metaphorised as a sought after "lost ethos" in a society which is thought to be "increasingly obsessed with private interest and restless" (Wang 2007: 288). It is hoped that by "(re)calling" Wu's "patriotic" story, and thus his ethos, his nation-loving spirit would touch the hearts of the Chinese people and the spirit would "return" to China. The publication of Wang's book came at a time when the Chinese authority was promoting "hexie shehui" (和谐社会 or harmonious society) and "weiwen" (维稳 or maintaining stability) as a strategic response to growing income disparity and social inequality in the country since 2004. It was a historical juncture when the then new leadership of China, $\mathrm{Hu}$ Jintao/Wen Jiabao Administration, faced the dual challenges of post-SARS healthcare reconstruction and economic crisis (de Haan 2010).

Later, more stories of $\mathrm{Wu}$ were generated and circulated online. The frame that these online Chinese accounts use to narrate Wu's stories is not very much different from the official patriotic trope of Han's and Wang's (2007), except that they tend to mention in passing Wu's involvement in anti-opium movement, some even entirely ignore his advocacy of cremation and education for girls in Malaya. Many online accounts merely reproduce the official patriotic trope. The underemphasis of Wu's association with Malaya is probably due to the perceived lack of connection between these facts and the community's present concern for China's public health service. Reading it in such a way, however, is to miss other subtle aspects underlying the post-SARS narratives of $\mathrm{Wu}$ in China. The underemphasis of Wu's legacies in Malaya, which is instrumental but not necessary for the reconstruction Wu's past into a patriotic or nation loving trope, I suggest, is to be read against the wider context of an authoritarian regime and against cultural politics in the region. By framing $\mathrm{Wu}$ as a "patriotic" plague fighter who made "sacrifices" for a nation, the post-SARS memories of Wu open up a discursive space to call forward the dedication of younger scientists and medical workers in China. ${ }^{20}$ The activity of "Finding Wu Lien-Teh" or "Re-discovering Wu Lien-Teh" is as much an activity to rediscover the "forgotten hero" as a search for the much needed yet perceived scarce breed of dedicated medical workers in the present. It simultaneously creates an image of a patriotic hero vis-à-vis the army of medical and health personnel who lack the nation loving ethos. Consequently, post-SARS disappointment and dissatisfaction about the condition of healthcare services is channelled 
against the lack of patriotism among medical workers and thus away from questioning the state authority.

Indeed, violence against health workers, an indicator of strong dissatisfaction over healthcare services in China, has been rising in the past decades. These attacks, nevertheless, predate SARS outbreak. Two existing strands of interpretation attribute the rising healthcare cost and deteriorating healthcare services in post-1979 China to different sources. One of them blames health workers for their corrupted practices, while another points finger at the structural problems of affordability and accessibility and the failure of state-led healthcare reform since $1979 .{ }^{21}$ Placed against this background, the patriotic trope appears to be a discursive vehicle for topdown political mobilisation that allows the expression of dissatisfaction concerning the present state of public health service, exposed by SARS, without being antagonistic to the authoritarian state. ${ }^{22}$ It is also a discursive exercise that appropriates an idealised and nostalgised trope to communicate the perceived deficient present. The past is "idealised" in the sense that common people's resentment against the perceived brutality of the intrusive anti-plague measure, such as control over people's movements and habits, imposed by $\mathrm{Wu}$ and his colleagues during the outbreak of Manchurian plague has been missing in the patriotic narrative. ${ }^{23}$ The complexities of the anti-plague interventions a century ago have been reduced to a doctorcentred nation loving narrative, which sings in tune with the authority's background vocals of "harmonious society" and "social stability."

But why did these Chinese accounts underemphasise Wu's connection to Malaya? I suggest that what underlies the minimalisation of Wu's legacies in Malaya is connected to an existing prevalent strand of Chinacentred Chinese nationalist discourse, which assumes the position of China as the cultural centre of and the "homeland" to Chinese, whether living inside or outside China, amidst rising identity politics in an increasingly globalised world (Ang 2001; Chun 1996; Koh 2013; Duara 1997). This China centred discourse tends to emphasise the connection of "Overseas Chinese" ${ }^{24}$ with China and obscure their association and affiliation with their host country. ${ }^{25}$ Despite being challenged and contested elsewhere, Chinese nationalist discourse has been fundamental to the construction of China as a cultural centre against the backdrop of global cultural power competition and rarely questioned in China (Ding 2008). Interpreted against this background, the China-centred patriotic narrative of $\mathrm{Wu}$, consciously or unconsciously reconstructed as such, is a reproduction and reinforcement of the dominant nationalist discourse which assumes China to be the centre that Chinese, whether born in or outside China, owe their allegiance to. Taken collectively, the SARS ignited memories of $\mathrm{Wu}$ in China seems to 
affirm the finding of earlier studies that social memories in authoritarian country tend to be intertwined with nationalist narrative (Loh 2013: 7).

In contrast to China, the accounts of $\mathrm{Wu}$ generated in the past three years in Penang are loaded with more information about Wu's engagement in social issues in Malaya, including his encounter of racial discrimination under the colonial medical service system, his role as president of the Penang Anti-Opium Association during his late twenties and his antigambling position. His advocation for women's education and cremation has been largely missing from most accounts, except the monograph authored by Ho Tak Ming which was reprinted and circulated by WLTS.

A major feature of the commemoration activities in Penang is creating a transnational image of $\mathrm{Wu}$ by weaving his connection with England, US, Germany, France and China without framing him as an "Overseas Chinese." A heroic anti-plague narrative coloured with transnational aspects of $\mathrm{Wu}^{26}$ is reconstructed to mark out Penang as a hub of global health and a destination of medical travellers from different places of the world. In January 2013, a delegation of 18 people from Penang led by Lee Kah Choon, special advisor to Penang Chief Minister, attended a commemorative symposium on $\mathrm{Wu}$ Lien-Teh in Harbin, China. Members of the delegation include representatives from the Penang state government, Penang Global Tourism, Penang Medical College and the then newly formed WLTS. Anwar Fazal, president of WLTS, disclosed that one of the major purposes of the trip was to "propose Penang as the next venue for the Dr. Wu Lien-Teh and Global Health Symposium in 2014" and to promote tourism, medical service and educational opportunities in the state ${ }^{27}$ Houses and places associated with $\mathrm{Wu}$ have been identified to form "heritage trail of Dr. Wu Lien-Teh" in Penang. ${ }^{28}$ On 9 March 2014, a bronze statue of Wu, gifted by the First Affiliated Hospital of Harbin Medical University, was placed in the campus of Penang Medical College.

The legacies of $\mathrm{Wu}$ Lien-Teh have been objectified, if not reduced, into architecture and places, for the purpose of promoting tourism, medical tourism and education in the region; his transnational pasts have been reconstructed as a marker to symbolise transnational elements and globalised image of Penang. Though taking place after SARS, the commemoration of $\mathrm{Wu}$ in Penang is not a response to the epidemic. Rather, it is driven by tourism industry, heritage conservation and the search for history in the aftermath of Georgetown being awarded UNESCO world heritage status.

Beyond the narratives of heritage conservation and tourism, Wu LienTeh's loyalty has been a contested aspect, especially among the circle of Sinophone Chinese Malaysian intellectuals, whose interest in $\mathrm{Wu}$ started a 
few years earlier than the tourism driven commemoration of $\mathrm{Wu}$ in Penang. These intellectuals tended to frame the significance of $\mathrm{Wu}$ in the context of rediscovering the legacies of several canonised Straits born Chinese, such as Lim Boon Keng, Song Ong Siang, Gu Hong Ming and Wu Lien-Teh. On 4 August 2012, Wong Sin Kiong, a Singapore based Malaysian scholar, delivered a talk entitled "Transregional Studies of Malaysian Chinese Society and Historical Figure: From the Case Study of the Great Doctor Wu Lien-Teh" at the Kuala Lumpur and Selangor Chinese Assembly Hall. ${ }^{29}$ One of the most discussed dimensions about $\mathrm{Wu}$ during the seminar was Wu's allegiance. Audiences who voiced their views tended to view $\mathrm{Wu}$ as having dual loyalty: $\mathrm{Wu}$ had been simultaneously patriotic to China as well as to Malaya.

The same dimension had already been raised in Wong's article back in 2007, though framed in a different manner. Wong reconstructed and juxtaposed the pasts of $\mathrm{Wu}$ together with the stories of another two Chinese intellectuals, all were born and grew up in Southeast Asia, but later drawn to work and live in China during Late Qing. In his account of Wu Lien-Teh, Wong questioned, if $\mathrm{Wu}$ had been patriotic to China, wouldn't have he stayed and offered his service in China during the Japanese invasion in the 1930s? Was it not possible that Southeast Asia born Chinese intellectuals, such as $\mathrm{Wu}$ Lien-Teh, were drawn to China merely out of their ambition to build a career there, instead of driven by patriotic motive? Wong argued, if these intellectuals' migration to China was merely career oriented, perhaps it should be understood as "traveling to China," instead of "returning to homeland." ${ }^{30}$

Whether framed in "dual loyalty" or "career oriented" trope, the narratives of Wu's loyalty call for contextualised reading. They are woven in a context in which the loyalty, identification and political affiliation of Chinese born in and/or living in Southeast Asia has long been subjected to competing and contradictory claims, either by the host country, by China or by their own ethnic community (Ang 2001; Duara 1997; Koh 2013). Indeed, the loyalty of Sinophone and Chinese educated Malaysians has always been placed under political limelight amidst racial and identity politics over linguistic allegiance in the country. Read against this context, both "dual loyalty" and "career oriented" narratives are attempts to negotiate, if not to resist, these contradictory demands, whether externally or internally imposed, on Chinese, who form an ethnic minority in many parts of Southeast Asia. Both tropes appropriate Wu's (dis)loyalty to communicate their present concern over identity and racial politics in the region. They are political readings of $\mathrm{Wu}$ to unsettle preconceived notions regarding the loyalty of the Chinese, without explicitly pronouncing the underlying 
identity politics in the region. These narratives and discussions about Chinese in the region at once contribute to discourses in the wider politics over Chinese identity. Both readings, however, would have been less likely, if $\mathrm{Wu}$ had not travelled wide enough to be reconstructed as a signifier of transnationality and hybridity. His transnational experience and hybridity allows multiple interpretations of his allegiance and thus eludes singular framing or interpretation.

\section{CONCLUSION}

Guided by Halbwachs' conceptual framework, this article has illustrated the place of transnationality, artefacts, locality and cultural politics in understanding the politics of memory regarding $\mathrm{Wu}$ Lien-Teh. Despite affirming the finding of earlier studies that memories in Southeast Asia tend to intertwine with nationalism, this article differs from these literatures in two ways. First, the existing scholarly works on social memories in Southeast Asia tend to use wars, conflicts and massacres to make a case for remembrance politics in the region. This small analytic exercise, however, illustrates that what appears non-contentious, such as memorialisation of a world-renowned biomedical scientist, is also a site where political and ideological forces play out. This article also differs from earlier studies regarding the role of state in manipulating memories. Unlike the remembrance of wars, conflicts and massacres, which each nation state in Southeast Asia often plays a direct and active part in constructing and managing the narratives, the memorialisation of $\mathrm{Wu}$ was accidentally triggered by SARS, then promoted by concerned scientists and intellectuals, and later exploited by the state authority in China, before it started spreading to and taking place in Singapore and Malaysia. The patriotic trope in China eventually becomes a space deployed by the state to allow popular expression of dissatisfaction, without being antagonistic to the state, regarding the perceived deficiency of public health service exposed by the outbreak. The nation loving narrative is now a discursive device for topdown political mobilisation to put blames against the lack of patriotism among the health workers, and divert popular attention away from questioning the state's responsibility and failure in reforming the health system. Health workers, instead of the state, become the target for blaming and correction.

Despite that the activities of memorialisation have been taking place in a transnational network, where people from different places are connected to one another and share stories about $\mathrm{Wu}$, the content of memory varies 
across space. In Singapore, $\mathrm{Wu}$ has been sung as an influential Straits Chinese. In Penang, he has been re-invented as a transnationalised marker to represent the globalised image of his hometown, for the promotion of tourism and global health hub. Finally, among the Sinophone Chinese Malaysian intellectual circle, Wu's (dis)loyalty has been appropriated to negotiate and unsettle the existing contradictory preconceptions of Chinese ethnic minority and their loyalty amidst the century long identity politics in the region. In sum, the stories about $\mathrm{Wu}$ have been variedly deployed by different historical actors, and differentially shaped by political and social dynamics in the region. His transnational experience and hybridity allows multiple interpretations of his allegiance and thus eludes singular framing or interpretation. Though the memories of $\mathrm{Wu}$ have been differentially framed, they are all narrated in present terms and tend to intertwine with existing nationalist narratives.

\section{NOTES}

* Por Heong Hong graduated from the School of Social Sciences, Universiti Sains Malaysia, in November 2014. Her research interests lie at the convergence of cultural studies and postcolonial inquiry of issues regarding health, illness, medicine, bodies, gender, nationalism and modernity. She is currently a research member of the Malaysian Ministry of Education funded project on "Traditional Knowledge," which examines how different forces and ideas-therapeutic, religious, scientific, and commercial - are interlaced with one another in the process of forming a regulatory framework for traditional medicine and herbal products in Malaysia.

1 Mark Gamsa's work (2006) has a comprehensive and critical discussion on the historiography of the Manchurian Plague. The existing historiography can be categorised into three types: (1) Wu Lien-Teh centred and triumphalist narrative of science advancement and modern medicine over plague and superstition (Flohr 1996); (2) a polyphonic narrative that decentres "great doctor" and tells the anti-plague campaign as a process characterised by competition between traditional Chinese medicine practitioners and biomedically trained scientists as well as between historical actors of different national origins, the employment of police force, cremation and quarantine in combating plague, and the disregarding of the lives of the lower class Chinese and the plague victims and thus their resistance against certain anti-plague measures (Gamsa 2006); and (3) globalisation narrative with a focus on foreign and local historical actors against the background of internationalisation of public health and science (Knab 2011). Gamsa (2006) has also pointed out that the eulogies of $\mathrm{Wu}$, science advancement narrative and "self-flattering" image of nation is common in China's "state-driven" history of the Manchurian plague. Though the postcolonial turn of historiography has changed the narrative from a "great doctor" one to one that is critical of medical authority and decentres nation state, the shift of 
narrative is for professional Anglophone readers and not for mass circulation. This, however, is not the focus of this article.

2 Different from "international," a government centred definition of interactions between nations; "transnational" refers to an actor centred notion of communication between nations, which includes exchange between NGOs, scholars, activists, people, scientists, etc. In reality, the two tend to overlap as a state-employed scientist can attend or speak in an international academic conference on his personal capacity.

3 Wang (2007: 310) mentioned the pivotal role of Wu Yu-Ling in transmitting the story of her own father, including providing historical details about Wu Lien-Teh to Wang's writing.

$4 \mathrm{Wu}$ was one of the 21 western style biomedical doctors in China who founded the association back in 1915.

5 Cheng, G-S. (2014), "Re-discovering" scientist Wu Lien-Teh ("重新发现"科学家伍 连 德 ). Zhongguo Kexue Bao, 25 July. Available from: news.sciencenet.cn/sbhtmlnews/2014/7/289944.shtm (accessed 26 Aug 2014)

6 Li, L. (2005), Wu Lien-Teh: "The pioneer of modern medicine in China" ("中国现代 医学先驱 "-- 伍连德). Hainei Yu Haiwai, 8 September. Available from: http://www.chinaqw.com/node2/node2796/node2883/node3178/node3209/userobject 6ai260127.html (accessed 28 Aug 2014).

7 Wang's (2007) book, largely drawn from Wu's (1959) autobiography, reconstructs Wu's story into a historical novel with $\mathrm{Wu}$ as the protagonist.

8 Zhou, L-T. (2009), English Wu Lien-Teh documentary (unfinished, only Chinese version completed), Zhong Guo Xin Wen Wang, 7 Jan 2009. Available from: http://www.chinanews.com/cul/news/2009/01-07/1518660.shtml (accessed 28 Aug 2014).

9 Editor of Fujian Education Publisher, which published Wang Zhe's Guoshi Wushuang Wuliende in 2007.

10 Zhou (2009).

11 Initially, Ong Lay Hong planned to produce the documentary in two languages; the English version was later aborted due to lack of funding.

12 Treasurer of Penang based Dr. Wu Lien-Teh Society, which was established in October 2012.

13 Quah, S-S. (2011), Wu Lien Teh. Anything Goes. 12 April 2011. Available from http://ssquah.blogspot.com/2011/04/wu-lien-teh.html (accessed 28 August 2014); Du, Z-Q. (2011), Gu Hong-Ming Yu Wu Lien-De. Guangming Daily, 31 May. Available from www.guangming.com.my/node/104663 (accessed 14 April 2014). Quah and Du are old Free Schools.

${ }^{14} \mathrm{Du}(2011)$.

15 Quah (2011).

16 Ibid.

17 Quah, S-S. (2012), The Dr. Wu Lien-Teh Society. Anything Goes, 16 Oct. Available from http://ssquah.blogspot.com/2012/10/dr-wu-lien-teh-society.html (accessed 28 August 2014).

18 Interviewed on 20 April 2014.

19 Emphasis added. 
20 Zhang, W. (2007), "Finding Wu Lien-Teh," Zhongguo Qingnian Bao, 5 September. Available from http://zqb.cyol.com/content/2007-09/05/content_1882816.htm (accessed 26 August 2014).

21 Huang, Y. (2013), "China's doctors are under attack," The Atlantic, 3 December. Available from: http://www.campussafetymagazine.com/article/chinese_hospital_ worker_arrested_in_7_stabbing_deaths (accessed 26 Nov 2014).

${ }^{22}$ See Liu (2004) for evaluation and critique of post-SARS public health in China.

23 See Gamsa (2006) and Lei (2010) for a more historically grounded account of Wu's anti-plague measure during the Manchurian outbreak. The perceived "brutality" of and resentment against coercive segregation of the sick and suspected cases, which was imposed by $\mathrm{Wu}$ Lien-Teh and his colleagues, cannot be dissociated from the fact that Western medicine offered no cure for the sick and the mortality rate in plague hospital was 100 percent. However, given that Chinese medicine was equally helpless in curing and preventing the disease then and the biomedical authority was confronting an unknown disease, both Gamsa (2006) and Lei (2010: 84) argued, the best available solution was to limit the plague from further spreading by isolating suspected cases and diagnosed carriers of pneumonic plague despite being perceived as brutal.

24 The term "Overseas Chinese" itself implies China as the centre of Chinese living outside China. On the contrary, Straits Chinese is a term that decentralises China as the core of Chinese identity.

25 Wang (2007) contributes three chapters to reconstruct the engagement of Wu's maternal uncles and other "Overseas" Chinese in the nationalist movement in late 19th and early 20th century of China.

26 "Tribute to plague fighter: Three-day symposium to honour the work of Penang-born Dr. Wu Lien-Teh," Star Metro, 13 February 2014, 6.

27 Looi, S-C. (2013), "Penang pays tribute to Dr. Wu Lien-Teh," New Straits Times, 9 January. Available from: http://www2.nst.com.my/life-times/sunday-life-times/-paystribute-to-dr-wu-lien-teh-1.198522 (accessed 4 July 2014); "Remembering a plague fighter," The Star, 13 Jan 2013. Available from: http://www.thestar.com.my/News/ Community/2013/01/11/Remembering-a-plague-fighter/ (accessed 4 July 2014)

28 "Suggested itineraries: The heritage trails of Dr. Wu Lien-Teh in Penang," MyPenang. Available from http://mypenang.gov.my/suggesteditem-126-the_heritage_trails_of_ dr_wu_lienteh_in_penang.pgt (accessed 20 April 2014).

29 I was present at the seminar.

${ }^{30}$ In contrast to Wong's (2007) account of Wu's loyalty, Wang (2007: 274) insisted that $\mathrm{Wu}$ was patriotic to China even he decided to leave the war-ridden country in 1937: "The decision of $\mathrm{Wu}$ [to leave China] is incomprehensible in the eyes of many. A man should take up his responsibility when his nation is in crisis. When the entire nation was engaged in the war of resistance [against Japan], shouldn't one join the people to meet the national crisis and contribute by participating in the war, rather than running away? ...Any ordinary man would not forget and stop worrying about his nation. If it happened ten or twenty years earlier when $\mathrm{Wu}$ was still young, he would have stayed without hesitation, followed and supported the government, and contributed by participating in the war. But he was then already a 60 year-old man, he wanted to serve his country but he could not find the energy." To quote Benedict Anderson 
(2006), Wang's account is a "reverse ventriloquism" to justify nationalism by speaking for the dead.

\section{REFERENCES}

Anderson, B. 2006. Imagined communities: Reflections on the origin and spread of nationalism. New York: Verso.

Ang, I. 2001. On not speaking Chinese. New York: Routledge.

Bong, S. 2014. Trauma, memory and transformation in Southeast Asia. In Trauma, memory and transformation: Southeast Asian experiences, ed. Bong, S., 312. Petaling Jaya: Strategic Information and Research Development Center.

Chun, A. 1996. Fuck Chineseness: On the ambiguities of ethnicity as culture as identity. Boundary 223 (2): 111-138.

de Haan, A. 2010. The financial crisis and China's 'harmonious society'. Journal of Current Chinese Affairs 39 (2): 69-99.

Ding, S. 2008. To build a 'harmonious world': China's soft power wielding in the global south. Journal of Chinese Political Science 13 (2): 193-213.

Duara, P. 1997. Nationalists among transnationals: Overseas Chinese and the idea of China, 1900-1911. In Ungrounded empires: The cultural politics of modern Chinese transnationalism, eds. Ong, A. and Donini, D., 39-60. New York: Routledge.

Flohr, C. 1996. The plague fighter: Wu Lien-Teh and the beginning of the Chinese public health system. Annals of Science 53 (4): 361-380.

Gamsa, M. 2006. The epidemic of Pneumonic Plague in Manchuria 1910-1911. Past \& Present 190: 147-183.

Halbwachs, M. 1992. On collective memory. Chicago: Univeristy of Chicago Press.

Ho, T-M. 2000. Doctors extraordinaire, 2nd ed. Ipoh: The Perak Academy.

Knab, C. 2011. Plague times: Scientific internationalism and the Manchurian Plague of 1900/1911. Itinerario 35 (3): 87-105.

Koh, E. 2013. Remembrance, nation, and the Second World War in Singapore: The Chinese diaspora and their wars. In Oral history in Southeast Asia: memories and fragments, eds. Kah, S. L., Dobbs, S. and Koh, E., 61-82. New York: Palgrave Macmillan.

Lee, K-H. et al. 2014. Dr. Wu Lien-Teh: Modernising post-1911 China's public health service. Singapore Medical Journal 55 (2): 99-102.

Lei, S. H-1. 2010. Constituting notifiable infectious disease and containing the Manchurian Plague (1910-1911). In Health and hygiene in Chinese East Asia: Policies and publics in the long twentieth century, eds. Leung, A. K. C. and Furth, C., 73-106. Durham: Duke University Press. 
Loh, K. S., Koh, E. and Thomson, A. 2013. Oral history and fragments in Southeast Asia. In Oral history in Southeast Asia: Memories and fragments, eds. Loh, K. S., Dobbs, S. and Koh, E., 1-24. New York: Palgrave Macmillan.

Liu, Y. 2004. China's public health-care system: Facing the challenges. Bulletin of World Health Organization 82 (7): 532-538.

Luesink, D. 2009. The history of Chinese medicine: Empires, transnationalism and medicine in China, 1908-1937. In Uneasy encounters: The politics of medicine and health in China, 1900-1937, ed. Borowy, I., 149-176. Berlin: Peter Lang.

Paez, D., Basabe, N. and Gonzalez, J. L. 1997. Social processes and collective memory: A cross-cultural approach to remembering political events. In Collective memory of political events: Social psychological perspectives, eds. Pennebaker, J. W., Paez, D. and Rime, B., 147-174. New Jersey: Lawrence Erlbaum Associates.

Radley, A. 1990. Artefacts, memory and a sense of the past. In Collective remembering, eds. Middleton, D. and Edwards, D., 46-59. London: Sage.

Schwartz, B. 1990. The reconstruction of Abraham Lincoln. In Collective remembering, eds. Middleton, D. and Edwards, D. 81-107. London: Sage.

Singapore China Friendship Association. 2011. Singapore China Friendship Association Bulletin, April.

Sorek, T. 2015. Palestinian commemoration in Israel: Calendars, monuments, and martyrs. Stanford: Stanford University Press.

Wang, Z. (王哲). 2007. Guoshi Wushuang Wuliende (《国士无双伍连德》). Fuzhou: Fujian Jiaoyu Chubanshe.

Wong, S. K. 2007. Returning intellectuals from Nanyang, state and society in late Qing: Gu Hong Ming, Li Deng Hui and Wu Lien Teh. In State and society in late Qing, ed. Zhong Guo She Hui Ke Xue Yuan, 617-630. Su Zhou: She Hui Ke Xue Wen Xian Chu Ban She.

$\mathrm{Wu}$, Li-T. 1959. Plague fighter: The autobiography of a modern Chinese physician. Cambridge: W. Heffer \& Son Ltd.

Wu, Y-L. 1995. Memories of Dr. Wu Lien-Teh: Plague fighter. Singapore: World Scientific Publishing Co. 